\title{
Creating and Maintaining Group Cohesion in Online University Classes
}

\section{Billunta Carter}

Kansai Gaidai University

\section{Elliot Patton \\ Kansai Gaidai University}

\section{Reference Data}

Carter, B., \& Patton, E. (2021). Creating and maintaining group cohesion in online university classes. In P. Clements, R. Derrah, \& P. Ferguson (Eds.), Communities of teachers \& learners. JALT. https://doi.org/10.37546/JALTPCP2020-46

Group cohesion, defined simply as the feeling of camaraderie and shared goals among the members of a class, is a fundamental goal of language teachers in Japan and around the world. The body of work on group cohesion in face-to-face classes is fairly extensive, but as a result of the coronavirus pandemic, the majority of university educators in Japan were forced to shift to some form of distance learning. This study considers the issue of how instructors were able to create and maintain group cohesion in online courses, and to what extent face-to-face classes could be replicated online. Twenty-seven university instructors responded to the survey, which consisted of several open-ended questions. The results of that survey are reported here, along with recommendations the researchers were able to assemble based on survey feedback.

集団の結束力とは、端的に言って、生徒が友情を構筑し目標を共有することと定義されるが、それは日本および世界中の語 学教員の目標である。対面授業における集団の結束力に関する研究はかなり広範囲に及ぶが、コロナウイルスの大流行の結 果、日本の大学教育者の大多数は何らかの遠隔教育を余儀なくされた。本論は、大学教員がオンライン授業で集団の結束力

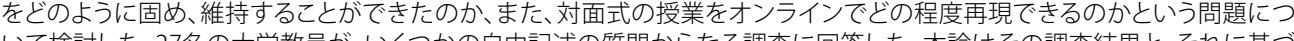
いて誒託した。27名の大学教員か、いくかの自由記述の質問からなる調査に回答した。本論はその調査結果と、それに基つ く提言を提示する $\square$ ducators around the world were caught off guard by the massive changes

necessitated by the novel coronavirus pandemic that shocked the world in 2020. Schools at all levels were profoundly affected, but perhaps the most groundbreaking changes were made at the university level. Universities in Japan, like those in many other countries, were put in a position to make decisions that affected the lives of millions of students and thousands of instructors. The central guidance from the country's Ministry of Education, Culture, Sports, Science, and Technology (MEXT) was that each university should devise its own educational plan. These plans incorporated varying degrees of both live and pre-recorded online content.

The authors of this paper are English instructors at one of the largest foreign language-focused universities in Japan and the majority of respondents in this paper are current or former instructors at the university. In order to lay the groundwork for this report, it is important to focus on this university's pandemic response, one which the authors of this study commend as strong and organized. The authors' university opted to delay its traditional early April start date for six weeks to allow (a) students to obtain the necessary technology for online study, and (b) instructors to familiarize themselves with the available tools of online instruction. The university purchased a campus-wide subscription to the online meeting software known as Zoom to augment its existing learning management software, Blackboard. It also vastly expanded its data storage and server capacity in order to accommodate on-demand courses. The majority of respondents to this survey opted to hold live, full-class meetings over Zoom. It is within this context that we discuss teachers' responses to the demands of online teaching.

The purpose of this article is to report on the results of a survey conducted between the spring and fall semesters of 2020 , at a point when instructors had time to submit final grades and reflect upon their experiences as online instructors during the sudden change of instruction format from April. Of specific interest for this study was the creation and maintenance of group cohesion in online instruction. Specifically, how did instructors try to foster a positive class atmosphere over the course of a class? How 
similar or different were these practices from what instructors would normally do in a face-to-face classroom? Finally, in a situation that calls for a new set of best practices, what practices were most effective for instructors as far as establishing and encouraging cohesion in their groups? In order to expound on this, it is first necessary to provide some background on group cohesion.

\section{Group Cohesion}

The concept of group cohesion, interchangeably referred to as group cohesiveness, comes to language education from the field of social psychology. In one early examination of the relationship between group cohesiveness and performance, Mullen and Copper (1994) laid out three conditions necessary for a group to consider itself to be cohesive: a desire on the part of the members to belong to the group; a sense of commitment to the group's tasks or missions; and a level of pride in the group. When these conditions are achieved, the group's sense of camaraderie and shared responsibility can result in an overall improvement in performance (Evans \& Dion, 1991). Following that, group cohesion can lead to a more pleasant and supportive classroom atmosphere and a higher perception of the effectiveness of the learning experience (Dörnyei \& Murphey, 2003).

Accordingly, group cohesion is something that can be affected by the instructor at several stages of a course. Ehrman and Dörnyei (1998) categorized the four main stages at which cohesion can be most affected by the instructor as group formation, which consists of what is colloquially called "ice breaking;" transition, during which the full identity of a group is established; performance, where the group must maintain its established cohesion; and dissolution, during which the risk of breakdowns in cohesion are highest. The teacher's influence on cohesion is largest at the onset of a course (Dörnyei \& Malderez, 1997), but there is no stage at which an instructor is powerless to affect group cohesion. It is this idea that prompted questions in the current study regarding maintenance of group cohesion as well as establishment.

There are several other important factors that potentially come into play in group cohesion. Dörnyei and Ushioda (2011) stated that the establishment of group norms by the instructor, particularly those related to classroom behavior, is crucial in establishing group cohesion. Additionally, Chang (2010) found that it is important to identify students who are particularly motivated towards language learning and do everything possible to encourage their participation. Along with this identification and encouragement of motivated students, efforts by the instructor to maintain a positive group environment, particularly those that are apparent to the students, can have a strong effect on students' perceptions of the cohesion of the group (Dörnyei \& Ushioda, 2011). A final, highly important factor in group cohesion is that students are able to feel that they have been able to interact effectively in smaller groups with the majority of the rest of the group. This feeling can be instilled by repeated, regular randomization of the members of small groups during classroom tasks (Liljedahl, 2015; Patton, 2021).

The role group cohesion plays in online learning was explored by Garrison et al. (2000). They provide a theoretical model that describes how interaction in three dimensions social presence, cognitive presence, and teaching presence - help give a more observable definition of group cohesion in the medium of online education. More specifically, the level of voluntary student engagement influences the level of resulting group cohesion (Altebarmakian \& Alterman, 2019). Issues that might affect levels of engagement have shown specific results affecting group cohesion in online learning. Lee (2020) found that audio lag could potentially undermine the trust found within groups learning online. Furthermore, aspects such as being able to see one's image on screen and lack of direct eye contact contribute to a lack of confidence in the resulting social interaction. Finally, Lowenthal et al. (2015) came to the conclusion that online courses are rated lower overall according to student evaluations, thus showing that the inherently difficult to overcome nature of online learning might diminish the potential for group cohesion. In the present investigation, the authors hoped to contribute to the study of group cohesion in online learning environments.

\section{Methodology}

The current study follows a faculty survey model established by Senior (2001), but with a specific focus on the relationship between group cohesion strategies and online instruction. The authors specifically sought out experienced university teachers who were forced to make massive adjustments during a crisis year in education. The authors deliberately created an open-ended survey rather than multiple-choice or Likert-scaled items; the intent behind this was to elicit interview-like responses. The authors entered the study with the following goals: (a) to obtain a sample of experienced instructors' opinions regarding successes and failures in creating group cohesion in online classes; (b) to identify both general and specific trends in classroom management and the establishment and maintenance of cohesion; and (c) to generate a set of recommendations for best practices for instructors seeking clear ideas for promoting group cohesion in an online setting. 
The survey consisted of seven main questions, all of which allowed for lengthy, open-ended answers. In order to ensure a common understanding of group cohesion, a detailed explanation was provided at the beginning of the survey. This explanation cited Mullen and Copper's (1994) characteristics of group cohesion and Ehrman and Dörnyei's (1998) stages of group cohesion (discussed above). Since the concept of group cohesion, like other social psychological variables, carries with it the risk of subjectivity and differences in interpretation among instructors, the hope was that clearly defining it in the introduction would result in a more common interpretation. Twenty-seven university instructors working at four different universities responded to the survey. All respondents, regardless of language of instruction or subject matter, had access to Zoom or a similar online live meeting application, as well as online learning management software (LMS), such as Blackboard or Moodle, which was recommended, set up, and paid for by their respective universities. All gave informed consent to participate. As this was a collection of faculty opinions with no experimental condition, the authors were advised that permission from the university's institutional review board was not required. Most instructors $(\mathrm{n}=21)$ were native English speakers teaching courses in English, but other respondents $(n=4)$ were Japanese instructors teaching primarily in English, and two respondents were Japanese instructors teaching in Japanese. All survey responses were provided in English. Some respondents asked that their responses not be explicitly used as quotes, but consented to their responses being considered for analysis of trends or for aggregation of frequently stated ideas.

The results section will be separated based on the various questions of the survey, and the discussion section will include recommendations that the authors were able to reach based on colleagues' responses. By including specific answers and direct quotes, the hope is that readers are able to leave this article with useful tips from fellow instructors.

\section{Results}

The results below are separated based on the individual items of the survey. Although the authors attempted to present a unified definition of group cohesion to respondents at the beginning of the survey, it is important here to stress the possibility of individual, subjective interpretations of what contributed to cohesion. Where one respondent might note active participation in group activities as evidence of cohesion, another might consider the length of interaction, level of alacrity, eagerness in completing classroom tasks, or even the respondent's own personal sense of a positive classroom atmosphere as proof of a cohesive group.
Q1: What measures did you undertake at the onset of your spring 2020 online course(s) to increase the potential for group cohesion?

Nearly all respondents shared their efforts as far as creating specific assignments designed to encourage collaboration and interaction early in their courses. For many respondents, the promotion of group cohesion necessitated that the normal practice of "icebreaker" activities had to be extended several weeks into the course rather than solely during the first meetings. Another frequently mentioned point was creating assignments related specifically to the challenges of online learning. One respondent reported this regarding the use of the discussion board feature of Blackboard as an early measure: "In the spring, my goal was as much as possible to re-recreate what I had been doing in the classroom. I did the usual ice breaking activities, but added the use of discussion boards as a way for students to get to know each other."

Other measures taken at the beginning of the course that respondents found to be successful included assigning a paragraph encouraging students to share their views on e-learning; creating in-depth surveys that other classmates could read in order to find areas of common interest; using a shared Google Slide document - or a shared blog in writing classes - in which everyone could introduce themselves to class members; and the formation of class groups on external social network applications such as Line. Three respondents stated that they felt it was useful to allow students time after class without the instructor; this was done by leaving the Zoom meeting but not closing it, allowing students the option to remain and socialize.

Q2: What, if any, adjustments did you make over the course of the spring 2020 semester to improve group cohesion?

This question was intended to explore adjustments made during the Spring 2020 semester with regards to group cohesion and, furthermore, to compare those adjustments to typical adjustments made in face-to-face classes. Overall, the respondents made very few changes at the outset of the course. However, for those who did make adjustments, the most common had to do with providing students with more time to complete activities (even those activities that students were previously familiar with completing) and providing less direct oversight. "Less direct contact" can be defined for these purposes as an instructor speaking less in the breakout room (when a highly specific task is defined) and also providing students time at the beginning or end of class to communicate with each other. 
One pertinent quote that seemed to exemplify many comments was: "It seemed like there was a time lag or that students needed more time to talk online versus in person." In essence, more time to interact, with what is, at least from the researchers' perspective, a counterintuitively lower amount of intervention from the instructor, seemed to provide a strong push towards greater group cohesion.

Q3: What practices helped most to establish, preserve, or improve group cohesion over the duration of your spring 2020 online course(s)?

Respondents were asked to describe the practices they found most useful over the course of the semester. The results of this question came in two areas. First, the use of Breakout Rooms in Zoom for the purpose of creating smaller groups, thereby encouraging students to feel more comfortable interacting more; and secondly, some sort of manipulation (extension) of ice breaking activities. This was commonly accomplished through Blackboard blogs and discussion boards. It seems that the class dynamic created by face-to-face ice breakers in previous semesters was more effective for maintaining group cohesion than any practices respondents felt they were able to develop in 2020 . One process running counter to randomization was to establish pre-assigned Breakout Rooms based on teacher-assessed speaking skills and gathering lower-level students into a separate group. As one respondent stated: "Essentially, tailoring the class to the needs of the higher-level students." Other respondents successfully incorporated the following strategies:

- Keeping the number of students in Breakout Rooms low. Many respondents determined that smaller groups led to more successful activities.

- Holding warm-up chat sessions in which students could interact freely for 5-10 minutes at the beginning of class.

- Allowing students, the opportunity to share and comment on the student blogs, something the respondent felt removed the element of time pressure.

- Encouraging students to participate by introducing optional speaking time. Students who didn't feel like speaking could leave the Zoom.

Q4: Which practices, if any, were you able to reproduce most effectively from your face-to-face classes in your online courses?

The purpose of this question was to determine if there were any face-to-face practices that instructors could seamlessly use or easily transition from the change in instruction format with regards to group cohesion. The responses here were very clear. The easiest teaching style was lecturing, and several respondents stated that they often resorted to this to the potential detriment of establishing group cohesion. An additional reproducible task was reviewing student work activities, both from home and in class, although again, no respondent stated that this had a positive effect on group cohesion. Respondents found success reproducing face-to-face methods via creating small groups with assigned roles. Additionally, respondents stated that covering the course textbook activities in accordance with the intended order of the textbook allowed for smoother classes. In essence, though, the prevailing sentiment among respondents was that the number of considerations due to the new teaching modality were so vast that it would basically be more beneficial to approach the semester with a fresh start, essentially abandoning much of their traditional classroom approach. One respondent summarized it quite succinctly: "This is hard to answer because I felt I had to overhaul every $\mathrm{d}$ *mn bit of my teaching."

Q5: What problems or limitations did you identify as the online course progressed, and what actions did you take to rectify these issues?

There were quite a few problems and limitations that presented themselves to respondents over the course of the semester. The authors attempted to avoid an examination of technical issues (e.g., connectivity), as they were probably universal. With regards to feedback and assessment, it was clearly reported by several respondents that it took much longer to do online what could have been accomplished more expeditiously in a face-to-face setting. Respondents also stated that regarding their students' motivation, the decrease was palpable, and the attendance showed a similar trend. Some specific issues noted by respondents:

- Grading and student feedback took twice as long. (Note: This respondent provided the solution of including shared keywords to encourage students to participate in answering questions.)

- Student motivation and quality/productivity of group work was significantly lower, and "was remarkably worse in Zoom class" than in face-to-face classes.

- Zoom fatigue - this applied both to students and teachers.

- The impossibility of listening to Breakout Room groups unless directly participating. This made it much more difficult to enforce an English-only environment. 
- Students who were improperly leveled reduced the cohesion in the class. “...online learning really magnifies the problem of students who can't properly do an activity together."

Q6: What level of importance do you place on the perceived level of cohesiveness in your groups, both online and face-to-face?

Due to the fact that the authors were looking closely at the variable of group cohesion, it was determined that it would be helpful to readers to create a baseline to establish the importance. The results were not surprising; most respondents believed that group cohesion is highly important in terms of challenging students to take chances and perform in class. One respondent stated that group cohesion is "essential to learner confidence, willingness to interact, and risk-taking in the $\mathrm{L} 2$ classroom." A few respondents felt the level of importance they place on group cohesion has decreased ove time, and others shared the sentiment that it is almost completely out of their control regardless of the medium. One respondent's quote exemplifies this: "I used to believe held more influence over (group cohesion). I don't anymore."

Q7: With regard to establishing, maintaining, or improving group cohesion, what recommendations or advice would you give to those aiming to ensure best practices in online teaching?

The respondents of the survey had several overarching suggestions for future best practices that the authors have categorized into three main points:

Showing empathy. More than a dozen respondents shared their experiences with allowing for students to air their problems or concerns and offering an outlet to vent frustrations, whether in discussion or in writing. It is important to remember that the unprecedented events of 2020 left students with no point of reference for coping with the situation, and one of the few outlets open to them was through classroom communication

Finding more creative ways of allowing students to interact. This was something that several respondents stated was mutually decided between themselves and the students. For a few respondents, social networking assumed a more primary role. For others, discussion boards on platforms like Blackboard led to more fruitful interaction. Finally, for some respondents, the assigning of homework assignments to cohorts rather than to individuals, despite the potential for free ridership, seemed to increase both extracurricular and in-class interaction among students.
Making up for the lack of communication before, after, and outside of the class as much as possible. Perhaps the most pertinent quote received regarding this was "(giving) students time to bond and socialize about everyday things is very important to developing a bond so students can then talk about academic things later."

\section{Discussion and Conclusion}

Based on the above answers, the authors of this study were able to identify trends and assemble a set of recommendations for best practices in online education. One of the main trends was that teachers viewed the Spring 2020 semester as a "one-off;" in other words, many did not do an exceptional amount of extra preparation or invest a sizable amount of resources into the online experience because, reasonably, it was assumed that classes would return to face-to-face format in September, 2020. As a result, they did not spend a significant amount of time familiarizing themselves with the technology offered. In particular, it is recommended that teachers learn the fundamental workings of breakout rooms- or their corollary function in other applications - and the capabilities that one has and does not have regarding student interaction.

A powerful quote from a respondent was that "it is not possible in the virtual classroom to replicate the level of cohesiveness naturally attained in face-to-face interaction. It may be the single greatest disadvantage after technical issues." While an attitude favoring overcoming these obstacles is of paramount importance, it seems absolutely necessary that teachers accept the limitations of the format. At some point, techniques that allow for an equivalent amount of group cohesion in online classes might be reached, and perhaps technology will reach a point that allows for it, but in lieu of forcing the issue, teachers can benefit from the following recommendations for best practices:

1. Allowing more time for activities in Breakout Rooms, as well as more time to cover and review assigned material in online sessions, might enable students to acquire a sense of familiarity and camaraderie, noted by Mullen and Copper (1994) as an important characteristic of group cohesion, more effectively. The responses we received gave the impression that instructors experienced significant difficulty accomplishing as much online as one could face-to-face. While this was a frustration, going in with realistic expectations could do more than reduce stress on the teacher and allow for more productive classes. It could have the added effect of increasing students' perceived level of group cohesion.

2. In order to create and maintain group cohesion, which tends to form as the result of 
effort on the part of both teachers (Ehrman \& Dörnyei, 1998) and motivated students (Chang, 2010), icebreaker-style activities will need to be a semester-long feature of online courses as opposed to something done during the beginning of the course. Measures to compensate for the reduced opportunity of students to communicate casually before, during, and after class, such as interaction on social media and discussion fora, need to be taken into consideration.

3. Technologically speaking, as Lee (2020) noted, screen fatigue is a major issue, especially with environments like Zoom that involve a constant on-camera presence. To make a statement that fatigue with the meeting structure could negatively impact group cohesion would require further research. However, one of our takeaways from this survey was that instructors felt that the draining nature of long meetings without breaks reduced both motivation and cohesion. It is important to remember that students might feel similarly, and that the online course experience has the potential to be more draining for students than face-to-face classes as well. Many respondents pointed out that allowing time for breaks, especially in 90-100-minute meetings, seemed to help maintain the energy level of students.

Above all, it was found that teachers seemed to feel that group cohesion is not so much created through curriculum design as it is in allowing extensive opportunities for interaction among students and in presenting an empathetic presence as course instructor.

\section{Bio Data}

Billunta Carter currently lives in Osaka, Japan. He is interested in teaching academic writing as a process and encouraging students to read in foreign languages for pleasure. He is an avid fan of exercise and all things active. He also enjoys culinary endeavors and listening to and creating podcasts. <bcarter7@kansaigaidai.ac.jp>

Elliot Patton has spent nearly a dozen years teaching in Japan. He is interested in investigating social psychological principles in the classroom, particularly group cohesion and group formation in task-based learning and teaching. He also plays guitar in two bands composed primarily of other university professors. <elpatton@kansaigaidai.ac.jp>

\section{References}

Altebarmakian, M., \& Alterman, R. (2019). Cohesion in online environments. International Journal of Computer-Supported Collaborative Leaning, 14, 443-465. https://doi.org/10.1007/s11412-01909309-y

Chang, L. (2010). Group processes and EFL learners' motivation: A study of group dynamic in EFL classrooms. TESOL Quarterly, 44(1), 129-154. https://doi.org/10.5054/tq.2010.213780

Dörnyei, Z., \& Malderez, A. (1997). Group dynamics and foreign language teaching. System, 25, $65-$ 81. https://doi.org/10.1016/S0346-251X(96)00061-9

Dörnyei, Z., \& Murphey, T. (2003). Group dynamics in the language classroom. Cambridge University Press. https://doi.org/10.1017/CBO9780511667138

Dörnyei, Z., \& Ushioda, E. (2011). Teaching and researching motivation (2nd ed.). Routledge. https:// doi.org/10.4324/9781315833750

Ehrman, M. E., \& Dornyei, Z. (1998). Interpersonal dynamics in second language education: The visible and invisible classroom. Sage.

Evans, C. R., \& Dion, K. L. (1991). Group cohesion and performance: A meta-analysis. Small Group Research, 22, 175-186. https://doi.org/10.1177/1046496491222002

Garrison, D. R., Anderson, T., \& Archer, W. (2000). Critical inquiry in a text-based environment: Computer conferencing in higher education model. The Internet and Higher Education, 2(2-3) 87-105. https://doi.org/10.1016/S1096-7516(00)00016-6

Lee, J. (2020, June 27). A neuropsychological exploration of Zoom fatigue. Psychiatric Times. Retrieved from https://www.psychiatrictimes.com/view/psychological-exploration-zoomfatigue/

Liljedahl, P. (2015). The affordances of using visually random groups in a mathematics classroom. In Y. Li, E. Silver, \& S. Li (Eds.), Transforming mathematics instruction: Multiple approaches and practices. Springer. https://doi.org/10.1007/978-3-319-04993-9_8

Lowenthal, P. R., Bauer, C., \& Chen, K. Z. (2015). Student perceptions of online learning: An analysis of online course evaluations, American Journal of Distance Education, 29(2), 85-97. https://www.doi.org/10.1080/08923647.2015.1023621

Mullen, B., \& Copper, C. (1994). The relation between group cohesiveness and performance: An integration. Psychological Bulletin, 115(2), 210-227. https://doi.org/10.1037/0033-2909.115.2.210

Patton, E. (2021). A classroom study of the effect of visible vs blind randomization on class atmosphere in group discussion activities. Journal of Inquiry and Research, 13(1), 65 - 80.

Senior, R. (2001). Creating safe learning environments: Developing and maintaining group cohesion. Intercultural Education, 12(3), 247-259. https://doi.org/10.1080/14675980120087462 